\title{
Illustrations and Tables
}

\section{Black and White}

Figure I.1. The Half Moon at the Highlands engraving 2

Figure 1.1. General map of the northeastern United States and eastern

Canada showing Grenvillian basement rocks 10

Figure 1.2. General geologic map of the Highlands from Connecticut to

Pennsylvania 12

Figure 1.3. Chart of geological features and events during the Rodinian and

Pangean cycles 13

Figure 1.4. Geologic map of the Hudson Highlands region of New York 16

Figure 1.5. (a) Outcrop of the metasedimentary gneiss with recumbent folds.

(b) Upright open fold in quartzofeldspathic gneiss 17

Figure 2.1. Map of geomorphic and glacial features of the Highlands 28

Figure 2.2. (a) Till near Mount Arlington, N.J. (b) Lacustrine fan deposits near Buttzville, N.J. 35

Figure 2.3. Map of area around Newfoundland, N.J. 36

Figure 2.4. Map of area around Long Valley, N.J. 37

Figure 2.5. A typical valley-fill aquifer in the northern Highlands 40

Figure 3.1. Map of major soils in New Jersey portion of the Highlands 47

Figure 4.1. Cross-section of bedrock aquifer flow systems 62

Figure 4.2. Cross-section of glacial valley-fill aquifer flow systems 63

Figure 4.3. Groundwater withdrawals by aquifer and by state 65

Figure 4.4. The hydrologic cycle of a watershed 68

Figure 4.5. Mean monthly precipitation for Long Valley, N.J. 69

Figure 4.6. Relation of total annual precipitation to total annual stream

discharge, baseflow, and direct runoff for the Pequest River in Pequest,

Warren County, N.J. 70

Figure 4.7. Long-term groundwater-level trends in selected New Jersey

Highlands aquifers 73

Figure 4.8. The effect of increasing watershed impervious surface on streamflow 75 
Figure 4.9. Map of New Jersey urban land use and levels of macroinvertebrate community impairment 78

Figure 5.1. Use of Highlands water supplies by New Jersey municipalities

Figure 6.1. Pollen diagram from Spruce Pond, N.Y. 111

Figure 6.2. Frequency of tree species in the Highlands region in the eighteenth century $\quad 117$

Figure 6.3. Map of New Jersey Highlands forest cover as of $1890 \quad 119$

Figure 6.4. Market for manufactured forest products within New Jersey in 1899122

Figure 6.5. Wintertime photograph of an abandoned Highlands farm

Figure 6.6. Forest composition in southeastern Connecticut before and after the chestnut blight 125

Figure 7.1. Forest-wide aboveground live tree biomass in the Black Rock Forest 139

Figure 7.2. Size structure of trees of three species in the Black Rock Forest 141

Figure 7.3. Isopleth maps of average annual $\mathrm{pH}$ and of total inorganic nitrogen deposition in precipitation in 2007 at sites around the eastern United States 143

Figure 7.4. Distribution of forest stand ages within the Highlands 146

Figure 8.1. Distribution of major wetland types within each state 163 Figure 8.2. Hydric soils of the Highlands 166

Figure 11.1. Beckley Furnace, East Canaan, Conn. 233

Figure 11.2. Plan and elevation map of the Richard Mine 237

Figure 11.3. Photos of a charcoal mound constructed as a demonstration at Hopewell Furnace 238

Figure 11.4. Map showing the route of the Morris Canal and important railways associated with the New Jersey Highlands iron industry, $1860 \quad 240$

Figure 11.5. Open-pit mine excavation at the Cornwall Ore Banks, Pa., circa 1880s 243

Figure 11.6. Map of selected ironworks of the Highlands 244

Figure 11.7. The processing facility containing magnetic ore separator at Edison's Iron Works, Ogdensburg, N.J. 252

Figure 12.1. Highlands cropland and pasture cover, 1850-2007 263

Figure 12.2. Population trends for the Highlands region within the four Highlands states, 1850-2010 265

Figure 12.3. Percent change in population and housing units for the four Highlands states (1970-2010) 266

Figure 13.1. William Thompson Howell hiking with companion, circa $1910 \quad 277$

Figure 13.2. "Our Best Wild Up and Down Country" 282 
Figure 13.3 Storm King Mountain, at the northern gate of the Hudson Highlands 284

Figure 15.1. Impact of build-out on additional population, impervious surface, housing units, and buildable acres in the Highlands region by state $\quad 319$

\section{Color Plates}

Color plates appear between pages 178 and 179.

1. Satellite image map of the Highlands region

2. Highlands region reference map

3. Oley Valley in the Reading Prong of the Pennsylvania Highlands

4. Map of Highlands aquifers

5. Map of groundwater withdrawals

6. Map of annual domestic well withdrawals

7. Map of principal river basins with selected major gaging stations

8. Map of mean annual precipitation, 1971-2000

9. Map showing the baseflow index in the Highlands

10. Map of major drinking water supply reservoirs and principal river basins in the Highlands

11. Map of forest cover in the Highlands

12. Oak-dominated ridgetop and slope forests in the New York Highlands

13. Connecticut Highlands forest near Granby

14. Pennsylvania Highlands forest near Furnace Hills

15. Map of typical wetland occurrences in Connecticut and New Jersey

16. Shallow emergent marsh (Wawayanda State Park, N.J.)

17. Calcareous fen community (sloping fen in Sharon, Conn.)

18. Dwarf shrub-leatherleaf bog with beaver lodge (Edison Bogs, N.J.)

19. Red maple-highbush blueberry community (Pyramid Mountain, N.J.)

20. Lady's slipper (Cypripedium reginae)

21. Eurasian purple loosestrife (Lythrum salicaria)

22. Swamp pink (Helonias bullata)

23. Garlic mustard (Alliaria petiolata)

24. Distribution maps for American bittersweet and Oriental bittersweet in the NYMF range

25. Bobcat (Lynx rufus)

26. Golden-winged warbler (Vermivora chrysoptera)

27. Needham's skimmer dragonfly (Libellula needhami)

28. Courting pair of timber rattlesnakes (Crotalus horridus)

29. Hopewell Furnace and Cast House

30. Tuyere entrance with pipe to tub bellows 
31. Front of furnace inside Cast House

32. Map of population change at a municipal scale, 1950-2010

33. Early Mt. Gretna postcard, "An Early Morning Row"

34. Mt. Gretna Hall of Philosophy

35. Population density of the mid-Atlantic and southern New England urban areas in proximity to the Highlands

36. Map of New Jersey municipalities' conformance to the Regional Master Plan

\section{Tables}

Table 3.1. Soils of the Highlands of New Jersey 48

Table 7.1. Characteristics of Forest Inventory and Analysis (FIA) Plots 134 Appendix 9.1. List of 21 Globally Rare, Threatened, and Endangered Plant Species 199

Appendix 9.2. List of 58 Invasive or Potentially Invasive Species 199 Appendix 10.1. List of Threatened and Endangered Animal Species

Table 12.1. Land-Cover-Change Estimates between 1980s-1990s and 2000s 268 